Varga Márk

\title{
FENNTARTHATÓ KÖZIGAZGATÁS - AZ ELEKTRONIZÁCIÓ SZEREPE AZ INGATLANOK NYILVÁNTARTÁSA KAPCSÁN
}

\author{
Sustainable Public Administration - The Role of Electronisation in Real Estate \\ Registration
}

Dr. Varga Márk LL.M. irodavezető, Nemzeti Közszolgálati Egyetem, Közigazgatási Továbbképzési Intézet, Igazgatói Iroda; doktorandusz, Nemzeti Közszolgálati Egyetem, Közigazgatás-tudományi Doktori Iskola,varga.mark@uni-nke.hu

Publikációmban bemutatom az ingatlanokra vonatkozó jogok bejegyzésének jogilag jelentös tényei feljegyzésének folyamatát érintö változásokat, a történeti elözmények ismertetésével, végig kísérve annak a folyamatnak a legfóbb állomásait, amelynek eredményeként a magyar ingatlannyilvántartási eljárás a jelenlegi formáját elérte. Tekintettel arra, hogy az ingatlanok adatai, az ingatlanokra vonatkozó jogok, valamint a jogosultak adatai nyilvántartásának eljárási szabályozása egy a közelmúltban indult projektnek köszönhetöen, az elektronikus eljárás eszköztárának a jelenleginél sokkal szélesebb körben történő alkalmazásával jelentős átalakulás előtt áll, fontosnak tartom felmérni azt, hogy a jelenleg elökészités alatt álló projekt milyen lehetöségeket hordoz magában. Ismertetem azokat az elvárásokat, amelyeket az elektronikus ügyintézési törvény a földügyi igazgatás számára is meghatároz, és amely elvárásoknak a modern magyar ingatlan-nyilvántartás is meg kell hogy feleljen annak érdekében, hogy az ügyfelek ügyintézési terheit csökkentse, az elektronizáció révén az eljárást egyszerüsítse, így növelve az ingatlan-nyilvántartási eljárás fenntarthatóságát.

\section{KulCSSZAVAK:}

telekkönyv, ingatlan-nyilvántartás, elektronikus ügyintézés, automatikus döntéshozatal, digitalizáció, fenntarthatóság

In my publication I present the changes affecting the process of recording the legally significant facts of the registration of real estate rights by describing the historical antecedents, accompanying the main stages of the process as a result of which the Hungarian Land Registry procedure reached its current form. Given that the procedural regulation of the registration of real estate data, real 
estate rights and data of rightholders is about to undergo a significant transformation through the much wider use of the electronic procedure toolbox due to a recent project, I consider it important to assess the opportunities of the project under preparation. I describe the requirements that the Electronic Administration Act also sets for the land administration, and which the modern Hungarian Land Registry must also meet in order to reduce the administrative burden on customers and to simplify the procedure through electronic means, increasing the sustainability of the property registration process.

\section{KeYwords:}

Land Registry, title register, electronic administration, automatic decision making, digitisation, sustainability 


\section{AZ INGATLANOK TELEKKÖNYVI NYILVÁNTARTÁSA HAZÁNKBAN}

\subsection{Az ingatlanok nyilvántartásának kezdetei}

Hazánkban a 13. századtól a hiteles helyek, azaz a káptalanok és konventek minősíthetők az első, az ingatlanok, illetve az azokra vonatkozó bizonyos jogosultságok nyilvántartására szolgáló jogintézményeknek. Ezek az egyházi szervezetek őrizték a különféle, ingatlanokat érintő dokumentumokat, illetve bejegyezték az azokban rögzített jognyilatkozatok tartalmát az általuk vezetett nyilvántartásba. ${ }^{1}$ A hiteles helyek e sajátossága a hatályos ingatlan-nyilvántartási rendszerünk, sőt valamennyi európai ingatlan-nyilvántartási rendszer alapvető jellemzője.

Kölcsönt az ingatlan zálogba adása révén is lehetett szerezni, amely kezdetben úgy történt, hogy a zálogkötelezett birtokba bocsátotta a zálogjogosultat, aki szedhette az ingatlan hasznait, beruházásokat végezhetett azon, amelyek ellenértékét a kölcsön visszafizetésekor a zálogtartó részére meg kellett téríteni. A zálogjog ilyen formában történő alapítása azonban az 1853. november 22-én kiadott Nyílt-parancs 19. \$-a alapján ${ }^{2}$ a szerződés érvénytelenségét vonta maga után. ${ }^{3} \mathrm{~A}$ nemesi és jobbágyföldek és az azokra vonatkozó jogosultságok, terhek nem voltak nyilvántartva. A 12-13. századtól a királyok szabad királyi városokat alapítottak, amelyek ezáltal kikerültek a földesúri joghatóság alól. Ezekben fejlődésnek indult az ipar és a kereskedelem, amelyhez a szükséges tőke rendelkezésre állása pedig a hitelélet kialakulását eredményezte. ${ }^{4}$ Ehhez arra volt szükség, hogy a hitelező védelme valamilyen módon biztosítva legyen. Erre szolgált az a gyakorlat, hogy az adós hitére és becsületére tett fogadalmat, vagy az, hogy az adós saját személyét adva zálogba nem fizetés esetén elvesztette szabadságát. ${ }^{5}$ Ennél azonban értékénél fogva sokkal nagyobb biztosítékot jelentettek a hitelek kapcsán az ingatlanok, így a városokban korán megjelent az igény a tulajdonukkal szabadon rendelkező polgárok részéről az ingatlanok és az azokra vonatkozó terhek nyilvántartása iránt. A 15. századtól, a tárnoki jog szabályai szerint az ingatlant átruházni, valamint azt zálogul adni csak a bíró és az esküdtek előtt lehetett, amelynek megtörténtét a hiteles könyvekbe bejegyezték. Kérelemre a könyvek tartalmáról, az azt vezető városi hivatalnokok okiratot állítottak ki. Ezeknek a könyveknek a tárgyát az egyes regisztrált ingatlanok képezték, míg az okiratok az ezen ingatlanokra vonatkozóan a könyvekbe bejegyzett jogok igazolására szolgáltak. ${ }^{6}$ Pozsony városának 1439-től négy részből álló telekkönyve volt. Sopron városának telekkönyvét 1480-ban

Fenyő György - Hidvéginé Erdélyi Erika - Papp Iván: Magyar ingatlan-nyilvántartási jog. Székesfehérvár, Nyugat-Magyarországi Egyetem Geoinformatikai Kar Általános Jogi Tanszék, 2007.

2 Káplány Géza: Telekkönyv, birtokrendezés, telekkönyvi átalakitás, betétszerkesztés - Telekkönyv I. Budapest, Athenaeum R. Társulat, 1890

Schnierer Gyula: Jelzálogi- és telekkönyvi rendszerek elmélete. Pest, Lauffer Vilmos, 1869.

Fenyő - Hidvéginé Erdélyi - Papp i. m. (1. lj.)

Zlinszky Imre: A magyar telekkönyvi rendtartás a mai érvényében. Budapest, Franklin Társulat, 1890. 1-2.

Fenyő - Hidvéginé Erdélyi - Papp i. m. (1. lj.) 
említik először, Kassán pedig a 16. században létezett telekkönyv, amely azonban megsemmisült. ${ }^{7}$ A telekkönyvek nemcsak a jogváltozást, hanem a jogok keletkezését, megváltozását és megszűnését is igazolták. ${ }^{8}$

\subsection{A betáblázási könyvek megjelenése Magyarországon}

A telekkönyvek mellett megjelentek az úgynevezett betáblázási könyvek is. Az 1723. évi CVII. törvénycikk rendelkezett a jelzálogjogoknak betáblázási könyvekbe történő betáblázásáról, a megyékben és a szabad királyi városokban. A betáblázás a célját - hogy e követelések részére elsőbbséget biztosítson - csak részben érte el, mivel az csak csőd esetén biztosított a jogosult részére elsőbbséget, átruházás esetén harmadik jogszerzőkkel szemben nem. A jelzálog hazai megteremtésével kapcsolatos egyik legfontosabb szabályozás az 1840. évi XXI. törvénycikk a követelések elsőbbség végetti betáblázásáról. A városokban az ingatlant, amelyre a betáblázás vonatkozott, egyedileg kellett meghatározni, míg a megyékben az általános betáblázás elve alapján az adósnak a megyében található összes ingatlanára kiterjedt, azonban a betáblázási könyvek csak azokat az ingatlanokat tartalmazták, amelyeket záloggal terheltek meg. A betáblázás kiterjedt a nemesi ingatlanokra is, ezek esetében a megyei közgyülés által kirendelt küldöttség mérte fel a birtokot, majd ezután összeírást készített, amely alapján külön jegyzőkönyvben megtörténhetett a betáblázás. Elrendelték továbbá a betáblázási könyvek és a földkönyvek egyesítését. ${ }^{9}$

\subsection{Telekkönyvi törvényjavaslatok}

Mivel a fenti szabályok hiányosságai (főleg a megyei ingatlanokra vonatkozó általános betáblázás) miatt egy a telekkönyvi törvény kidolgozására bizottságot állított fel, amely 1847-re készítette elő a nemesi fekvő javak telekkönyvéről és betáblázásáról szóló javaslatot. „A javaslat lényegesebb rendelkezései közt megemlíthető, hogy minden birtokos 3 éven belül köteles volt birtokát bejegyeztetni, ellenkező esetben a telekkönyvi jogok nem illették meg. Előírták a helységnek, a birtokos nevének, a birtok területének, művelési ágának, a birtoklás jogcímének és eladásnál a vételárnak a bejegyzését. A javaslat értelmében betáblázás csak meghatározott birtokra történhetett, ${ }^{10}$ egy követelés betáblázása csak egy birtokra történhetett (így egyetemleges jelzálog betáblázása sem volt engedélyezett). A javaslat a betáblázás feltételeként elöírta, hogy az okiratot a kibocsájtó, valamint két tanú írja alá, és abban a felek neve, a jelzálog összege, a jogcíme, a kikötött jelzálog

\footnotetext{
Káplány i. m. (2. lj.)

Fenyő - Hidvéginé Erdélyi - Papp i. m. (1. lj.)

Káplány i. m. (2. lj.)

Azaz érvényesült a különlegesség telekkönyvi alapelve.
} 
megjelölése és a betáblázásra vonatkozó engedély is szerepeljen." ${ }^{11}$ A javaslat számos újítása a mai ingatlan-nyilvántartási szabályozásban is visszaköszön. Így például az ingatlannyilvántartásba bejegyzés alapjául szolgáló okiratnak tartalmaznia kell az érintett ingatlan pontos megjelölését (település és helyrajzi szám szerint), valamint ha nem egész ingatlanra kérik a bejegyzést, akkor a tulajdoni hányadot; a jogváltozás jogcímét vagy a bejegyzést megengedő nyilatkozatot (bejegyzési engedély) az ingatlan-nyilvántartásba bejegyzett jogosult részéről. ${ }^{12} \mathrm{Az}$ okirati forma előírása kapcsán részben hasonló, részben különböző szabályokat találunk a javaslat és a hatályos törvényi rendelkezések összevetésekor. A javaslat értelmében új betáblázásnál az okiraton a nyilatkozat kiállítója mellett két tanú aláírására volt szükség, míg a hatályos törvényi elöírás a jelzálogjog bejegyzéséhez egyrészt közokirati vagy ügyvéd, illetve jogtanácsos által ellenjegyzett magánokirati formát határoz meg. Emellett teljesíthető a bejegyzés olyan magánokirat alapján is, amelyet a nyilatkozatot tevő hitelintézet képviselője szabályszerüen írt alá oly módon, hogy abból az aláíró nyilvánvalóan azonosítható. ${ }^{13} \mathrm{Ez}$ a szabály természetesen vonatkozik mind az egyoldalú nyilatkozatokra, mint például a törlési engedélyek, és mind a kettő vagy több fél részvételével megkötött és így több fél nyilatkozatát tartalmazó, szerződésekre is, ha az egyik szerződő fél hitelintézet. ${ }^{14}$

Az 1848 utáni időszakban kísérletek történtek az országos telekkönyvi rendszer létrehozására. Az Igazságügyi Minisztérium 1849. december 28-án kelt, erre irányuló javaslata a Magyarkoronaországot illető Országos Törvény-és Kormánylap 1850. évi 2. számában jelent meg, és 1850. március 1-jén lépett hatályba. A javaslat előirányozta a még telekkönyvezetlen ingatlanokról betétek szerkesztését, illetve a telekkönyvek járásbíróság általi továbbvezetését. 1850. augusztus 14-én kelt és ugyanezen lap 240. számában jelent meg a telekkönyvi eljárás szabályait tartalmazó rendelet, amely szabályok azonban a kívánt célt nem tudták elérni, az ezek alapján készült telek- és betáblázási könyvek számos, utóbb már nehezen javítható hibát tartalmaztak, így a jogalkotó a rendes telekkönyv felállítását határozta el. Ennek előkészítése érdekében több rendeletet is kiadtak: 1853. április 18-i, 1853. szeptember 16-i, az 1854. július 23-i és az 1855. február 26-i, amelyek a helyszínelési feladatokat megalapozó rendelkezéseket tartalmaztak. ${ }^{15}$ Ezek elrendelték az ingatlanok felmérését, helyszínelési jegyzőkönyvek összeállítását, majd ezekből telekjegyzőkönyvek felfektetését. ${ }^{16}$

11 Varga Márk: A telek- és jelzálogkönyvek magyarországi kialakulása és annak előzményei nemzetközi kitekintésben: Az 1855. évi telekkönyvi rendtartás. In Méhes Tamás - Téglási András (szerk.): A jövő közigazgatástudománya: A Közigazgatás-tudományi Doktori Iskola doktoranduszainak jubileumi tanulmánykötete. Budapest, Dialóg Campus, 2018. 227-236.

12 1997. évi CXLI. törvény az ingatlan-nyilvántartásról (Inytv.) 32. § (1) bek.

13 Inytv. 32. \$(3)-(5) bek.

14 A jogintézmény szabályozását lásd: 2013. évi CCXXXVII. törvény a hitelintézetekről és a pénzügyi vállalkozásokról.

15 Káplány i. m. (2. lj.) 27.

16 Fenyő - Hidvéginé Erdélyi - Papp i. m. (1. lj.) 17-18. 


\subsection{Az 1855. évi telekkönyvi rendtartás}

Ezen helyszínelési munkák befejezése után hirdették ki a telekkönyvi rendtartásról szóló 1855. évi, december 15-én kelt igazságügy-miniszteri rendeletet. A telekkönyv vezetésére az 1855. július 20-i igazságügy-miniszteri rendelet a megyei törvényszékek vagy a járásbíróságok mellett felállított császári és királyi telekkönyvi tanácsokat hozta létre, amelyek mellett működtek a telekkönyvi hivatalok. Ebben az időben háromféle telekkönyv volt ismert: az általános vagy rendes telekkönyv, emellett az úgynevezett központi telekkönyv ${ }^{17}$ és végül a bányatelekkönyv. ${ }^{18}$

Az 1855. évi telekkönyvi rendtartás vezette be Magyarországon a telekkönyvet, elöírva a telekjegyzőkönyvek továbbvezetését telekkönyvként, és a telekkönyvvezetés anyagi és eljárási szabályait is rögzítette. A telekkönyv egy község telekjegyzőkönyveinek összességét jelentette.

A telekkönyv az elnevezése ellenére nem egy hagyományos bekötött könyv, hanem különálló lapokból áll. ${ }^{19}$ A telekkönyv a hatóságok által vezetett olyan nyilvántartás lett, amelynek célja, hogy az ország ingatlanjait nyilvántartsa abból a célból, hogy az azokat terhelő jogokról és kötelezettségekről bárkit közhiteles módon tájékoztasson. ${ }^{20} \mathrm{~A}$ telekkönyvbe bejegyezték az ország valamennyi épületének és földrészletének a területét, rendeltetésmódját, tulajdonosának nevét és minden terhet, amely az ingatlanhoz kapcsolódik. A telekkönyv nyilvános volt, arról bárki feljegyzést készíthetett, és arról hivatalos másolat is kiadható volt. Az abba bejegyzett jog közhitelesnek minősült, azonban a rosszhiszemü ${ }^{21}$ vagy ingyenesen szerzőt ez a vélelem nem illette meg. ${ }^{22}$

A telekkönyvi és jelzálogrendszer, ${ }^{23}$ hogy törvényi céljait elérhesse, a nyilvánosság és a vele szoros kapcsolatban álló bejegyzés, a törvényesség, a rangsor és a különlegesség alapelvének kellett hogy megfelelő jogalapot biztosítson. ${ }^{24}$ A rendtartás egyik legfontosabb alapelve a bejegyzés elve, ${ }^{25}$ amelynek értelmében az ingatlanra vonatkozó dologi jogváltozás csak telekkönyvi bejegyzés útján jöhet létre, vagyis maga a bejegyzés hozza létre ${ }^{26}$ a dologi jogot, vagy szünteti meg azt. Az alapelv több mint 150 éve meghatározó rendezőelve

${ }_{17}$ Ilyen volt a vasút és a csatornavállalat központi telekkönyve, valamint az ipari jelzálogadóssággal terhelt iparvállalatok telekkönyve.

18 Horváth Attila: A magyar magánjog történetének alapjai. Budapest, Gondolat, 2006. 228-229.

19 Fehérváry Jenő: A magyar telekkönyvi jog vázlata. Budapest, Grill Károly Könyvkiadóvállalata, 1947. 4.

20 Fenyő - Hidvéginé Erdélyi - Papp i. m. (1. lj.) 17-18.

21 Rosszhiszeműnek minősül a szerző, ha a látszattal ellenkező valós helyzetet ismeri, vagy a körülmények között ismernie kellett volna. Részletes kifejtését lásd: Kenyeres János et alii: A magánjog alapjai. Budapest, HVGORAC, 2007. 120-124.

22 Horváth i. m. (18. 1j.) 228-229.

23 A zálogjogi nyilvántartás kifejezés helyett hatályos jogunk a „hitelbiztosítéki nyilvántartás”-t használja, és a nem lajstromozott ingókon, jogokon és kötelezettségeken alapított jelzálogjogokat és egyéb biztosítéki jogokat tartalmazza. Ismerteti: Méhes Tamás: Polgári jogi alapismeretek. Budapest, Nemzeti Közszolgálati Egyetem Államtudományi és Közigazgatási Kar, 2017. 82.

24 Fehérváry i. m. (19. lj.) 6-13.

25 Eintragungsprinzip.

26 Konstituálja. 
a hazai telekkönyvi jognak, hiszen a szabály azóta is töretlenül érvényesül: „A jog keletkezését, módosulását, illetve megszünését a bejegyzés hozza létre.” ${ }^{27}$ A telekkönyv szempontjából jelentős jogokat két csoportba sorolhatjuk: az elsőbe azok tartoznak, amelyek bejegyzése kötelező, ${ }^{28}$ a másodikba pedig azok, amelyek bejegyzése ugyan nem kötelezö, de a jog érvényesíthetősége szempontjából jelentősége lehet a bejegyzésnek. ${ }^{29}$ A nyilvánosság alapelve $e^{30}$ jelenti az előzőkkel összefüggésben azt, hogy a dologi jogviszonyok bárki által megismerhetőkké válnak, ami záloga a telekkönyv közhitelességének, és stabil alapot biztosít az ingatlanforgalom és a jelzáloghitelezés számára. Ezen elvvel összhangban az 1855. évi telekkönyvi rendtartás nem ismerte el a hallgatólagos és a magánjelzálog-alapítás jogszerüségét. Csak azok a jogok válhatnak dologi hatályúakká, amelyeket bejegyeztek a telekkönyvbe. Az alapelv korlátját jelenti a 3 éves elbirtoklás intézménye, amely az ez idő alatt az elbirtoklás tárgyát képező ingatlanra bejegyzett jogokat is érvénytelenné teszi sikeres elbirtoklás esetén. Ugyanígy áttöri az alapelvet, hogy bizonyos állami követeléseket törvényes zálogjog illeti meg. Az 1855. évi telekkönyvi rendtartás részben az osztrák polgári törvénykönyv telekkönyvet szabályozó anyagi jogi rendelkezéseire támaszkodva maga is szabályoz anyagi jogi kérdéseket, mégpedig oly módon, hogy esetenként azzal szöges ellentétben áll. ${ }^{31}$

\subsection{A telekkönyvi rendszerünk reformja}

Az 1853 után készült telekjegyzőkönyvek tartalma a valós állapotoknak nem felelt meg, tartalmuk fokozatosan elavult. ${ }^{32}$ A tényleges birtokosok telekkönyvi bejegyzése sokszor elmaradt, a rendtartás által szabályozott eljárás bonyolult és a kor hatósági eljárásaihoz képest túlságosan bürokratikus, hiányzik belöle a következetesség. Emellett problémát jelentett az is, hogy nem volt elegendő számú szakképzett telekkönyvvezető, segéd-telekkönyvvezető és telekkönyvi bíró. A hivatalnokok sokszor a túlterheltség miatt nem tudtak megbirkózni a beérkező ügyekkel, és hiányzott a hatóságok feletti felügyelet, az eljárások folyamatos ellenőrzése. A fenti hiányosságok orvoslása érdekében az igazságügyi miniszter 1883. február 6-ára tanácskozást hívott össze, amely a hiteltelekkönyvek átalakítását és a földadókataszteri adatokkal való kiegészitését tűzte ki célul, azaz javaslatot fogalmazott meg a telekkönyvek kataszteri adatokkal, így a kataszteri tiszta jövedelem adataival történő kiegészítésére, valamint a tényleges birtokosoknak a telekkönyvbe való bejegyzésére (bekebelezésére). 1883. július 31-én a telekkönyvvezetök nyújtottak be törvényjavaslatot az igazságügyi miniszternek az új telekkönyvek (betétek) elkészítése tárgyában. Az 1884. január

\footnotetext{
Méhes Tamás: A Polgári Törvénykönyv vázlata. Budapest, Dialóg Campus, 2017. 107.

Idetartoznak a dologi jogok: a tulajdonjog, a jelzálogjog és a telekteherjog.

Idetartozik az elő- és visszavásárlási jog, a bérleti és haszonbérleti jog, valamint egyes esetekben az opció.

Publizitätsprinzip.

Sárffy Andor: Telekkönyvi rendtartás. Budapest, A szerző kiadása, 1941. 23-25.

Fenyő - Hidvéginé Erdélyi - Papp i. m. (1. lj.) 18.
} 
3-án tartott tanácskozásra az igazságügyi miniszter újabb javaslatot terjesztett be, amely alapján elkészült egy harmadik törvényjavaslat, amelyet végül 1886. április 7-én terjesztettek be a képviselőház részére a telekkönyvi betétek szerkesztéséről címmel. A törvényjavaslat igazságügyi bizottság általi megtárgyalását és módosítását követően 1886. június 2-án általánosságban, illetve június 4-én részleteiben is elfogadta, majd 1886. július 22-én kihirdették, mint a telekkönyvi betétek szerkesztéséröl szóló 1886. évi XXIX. törvénycikket. ${ }^{33}$ Ez a törvény elrendelte a telekkönyvek (betétek) szerkesztését a telekjegyzőkönyvekböl, amely folyamat rendkívül lassan haladt, 1960-ra a községek harmadában továbbra sem készült el a telekkönyv. A törvény értelmében a telekkönyvezés tárgyát a forgalomképes és megterhelhető ingatlanok képezték. 1912-töl ${ }^{34}$ a telekkönyveket a királyi járásbíróságok vezették, míg a telekkönyvi bevezetéseket a telekkönyvi iroda (telekkönyvi hivatal) telekkönyvvezetője, illetve a telekkönyvi minősítésü segédhivatalnokok végezték. ${ }^{35}$

\subsection{A telekkönyvek vezetése a népköztársaság időszakában}

A telekkönyvek vezetése évtizedeken át változatlan formában zajlott, azon a népköztársaság jogalkotása csak kisebb korrekciókat hajtott végre. Ilyen változás volt a telekkönyvi eljárás szabályainak egyszerüsítése tárgyában meghozott 126/1950. (IV. 29.) MT rendelet, amely egyebek mellett megszüntette a telekkönyvi előjegyzés jogintézményét. A Polgári Törvénykönyvröl szóló 1959. évi IV. törvény (Ptk.) 1960. május 1-jei hatálybalépése sem változtatott érdemben a telekkönyvi szabályokon.

Bár a Polgári Törvénykönyv hatálybalépéséről és végrehajtásáról rendelkező 1960. évi 11. törvényerejü rendelet (Ptké.) hatályon kívül helyezte a felszabadulás elött alkotott polgári jogi tartalmú jogszabályokat, illetve jogszabályok ilyen tartalmú rendelkezéseit, ${ }^{36}$ azonban többek között a telekkönyvvel kapcsolatos, még hatályban lévő és a Ptk.-val, valamint a Ptké.-val ellentétben nem álló rendelkezések hatályban maradtak. ${ }^{37}$ Ezzel ellentétes álláspontot képvisel Matúz György, amikor kijelenti, hogy a telekkönyvről szóló 54/1960. (XI. 27.) Korm. rendelet és a 2/1960. (XII. 25.) IM rendelet 1961. február 1-jei hatálybalépéséig ex lex állapot keletkezett. ${ }^{38}$ Valójában a telekkönyvről szóló 54/1960. (XI. 27.) Korm. rendelet helyezte hatályon kívül a korábbi, telekkönyvre vonatkozó jogszabályokat. ${ }^{39}$

A fenti rendeletek a telekkönyvezés rendszerén, a betétek szerkezetén nem változtattak, és azok vezetése továbbra is a járásbíróság hatáskörébe tartozott. Bár a telekkönyv

\footnotetext{
Káplány i. m. (2. lj.) 36-39.

1912. évi LIV. törvénycikk a polgári perrendtartásról szóló 1911. évi I. törvénycikk életbeléptetéséröl.

Sárffy i. m. (31. lj.) 23-25.

Ptké. 95. \$.

Ptké. melléklet 2. pont.

Matúz György: Telekkönyvi rendszerünk kialakulása és müködése. Doktori értekezés rövidített változata. Szegedi Tudományegyetem Állam- és Jogtudományi Kar, 2003.

54/1960. (XI. 27.) Korm. rendelet 36. § (1) bek.
} 
a reálfólium elvén ${ }^{40}$ nyugodott, így minden ingatlant külön-külön betétbe kellett telekkönyvezni, azonban az állami tulajdonban álló külterületi földeket, a perszonálfólium elve szerint kellett nyilvántartani, így minden állami gazdaság részére külön betétet kellett nyitni. Ugyanígy kellett eljárni a tanácsok végrehajtó bizottságai esetében is, a belterületi beépítetlen földrészletek vonatkozásában. ${ }^{41}$

\subsection{Az egységes ingatlan-nyilvántartás létrehozása}

Az 1970-es években a jogalkotó a telekkönyv és az emellett működtetett állami földadókataszteri rendszer egyesítését határozta el. A két regiszter ugyanis az adattartalmukat tekintve átfedéseket mutatott. Emellett, bizonyos információk az egyikből hiányoztak, míg mások a másikból. Annak ellenére, hogy bizonyos tekintetben mindkét nyilvántartás közhitelesnek minősült, mégis sokszor volt ellentétes azok tartalma, elsősorban amiatt, hogy a változásokat különböző időpontokban vezették át.

Az egységesítés keretében 1972. január 1-jén a telekkönyvvezetési hatáskör a bíróságoktól a földhivatalokhoz került, ahogy a telekkönyvi hivatalok is integrálódtak a földhivatalok szervezetébe. Ezzel együtt megtörtént az új, egységes ingatlan-nyilvántartás anyagi és eljárási szabályrendszerének kidolgozása. Az ezt tartalmazó jogszabály az ingatlan-nyilvántartásról szóló 1972. évi 31. törvényerejü rendelet, valamint az ingatlan-nyilvántartásról szóló 1972. évi 31. törvényerejü rendelet végrehajtásáról rendelkező 27/1972. (XII. 31.) MÉM rendelet. Ezek a jogszabályok tartalmazták a telekkönyvi betétek alapján ingatlannyilvántartási tulajdoni lapok szerkesztésének folyamatát, a tulajdoni lap tartalmát, felépítését, az ingatlan-nyilvántartásba bejegyezhető jogokat és jogilag jelentős tényeket, azok jogosultjait és az ingatlanok adatait. ${ }^{42}$

Az ingatlan-nyilvántartási eljárás továbbra is papíralapú volt, az ügyfeleknek mind a kérelmeket, mind azok mellékleteit, az okiratokat papíralapon kellett benyújtani, ahogy a tulajdoni lap és térkép- és okiratmásolatok kiadása is papíron történt. Maga az ügyintézés is a több évszázada alkalmazott technikával zajlott. Igaz, a határozatok megszövegezéséhez már írógépet, a sokszorosításhoz pedig stencilgépeket használtak.

A legnagyobb horderejű változást az ingatlan-nyilvántartási eljárás technikáját illetően a 1994. február 4-én hatályba lépett, az ingatlan-nyilvántartásról szóló 1972. évi 31. törvényerejü rendelet módosításáról rendelkező 1994. évi V. törvény hozta el, amely előírta az ingatlan-nyilvántartás átállítását elektronikus gépi adatfeldolgozásra. Emellett kiadták az ingatlan-nyilvántartásról szóló 1972. évi 31. törvényerejü rendelet végrehajtására kiadott 27/1972. (XII. 31.) MÉM rendelet módosításáról rendelkező 25/1994. (V. 19.) FM rendeletet

$40 \quad$ A reálfólium elve szerint a nyilvántartás tárgya a dolog, ebben az esetben az ingatlan. A perszonálfólium elve értelmében a nyilvántartás a jogosultak szerint szerveződik, hozzájuk kapcsolódnak a dolgok, illetve a jogok.

${ }^{41} \quad$ Fenyő - Hidvéginé Erdélyi - Papp i. m. (1. lj.) 25.

42 Kurucz Mihály (2003-2004): Ingatlan-nyilvántartási jog. ELTE Jogi Továbbképző Intézet Ingatlanforgalmi szakjogász képzés jegyzet. 8-9. 
is, amely egyebek mellett meghatározta a gépi adatfeldolgozású tulajdoni lapok formátumát. A törvény szabályozása értelmében felhatalmazást kapott a földművelésügyi miniszter, hogy elrendelje az ingatlanok adatainak, valamint az ingatlanokhoz kapcsolódó jogoknak és tényeknek elektronikus gépi adatfeldolgozással történő kezelését azoknál a földhivataloknál, amelyeknél ehhez a személyi és tárgyi feltételek az adott költségvetési év kiadási (támogatási) előirányzatai között a központi költségvetésböl, illetőleg egyéb forrásból biztosítottak. ${ }^{43} \mathrm{~A}$ változtatás szükségességét a rendszerváltással bekövetkező társadalmi, gazdasági folyamatok indokolták, amelyek kihatással voltak hazánk ingatlanstruktúrájára is. Az ingatlanok száma megsokszorozódott, hiszen a termelöszövetkezeti földhasználatban álló földrészletek a kárpótlási és a részarányföldtulajdon-kiadási folyamat eredményeként többszázezer kisebb földrészletté darabolódtak; emellett a tanácsi lakásállomány a használók tulajdonába kerülve egymillió új tulajdont eredményezett. ${ }^{44}$

Az ingatlanok számának ilyen volumenű bővülése ellehetetlenítette a földhivatalok addigi eljárásrend szerinti müködését és az ingatlanoknak a hagyományos, papíralapú nyilvántartását, azon a változások manuális vezetését.

A magyar kormány és az Európai Közösség a PHARE (Poland and Hungary: Action for the Restructuring of the Economy) -segélyprogram keretében megállapodást kötött egy többéves fejlesztési projektre, amelynek célja a földhivatalok által kezelt tulajdoni lapi és térképi adatok számítógépesítése, ennek keretében az ingatlankataszter komplex, térinformatikai rendszerként való kialakítása számítógépesítéssel, új szolgáltatások kifejlesztésével, szabványosításával, a szakmai szabályzatok felülvizsgálatával és egyebek mellett új vezetői módszerek meghonosításával. Első lépésként 115 helyszínen telepítettek számítógépeket 1993 októberéig. A számítógépeket helyi hálózatba kapcsolták. Ezt megelőzően a földhivatali munkatársakat is továbbképezték, valamint a megyei rendszergazdák és rendszerfelelösök részére számítástechnikai tanfolyamokat tartottak. Mintegy hat és félmillió ingatlantulajdoni lap első részének adatait rögzítették a megyei földhivataloknál üzemelő szerverekre. Megkezdődött a földhivatali munkatársak részéről a tulajdoni lapok második és harmadik része adatainak felvitele az adatbázisba. ${ }^{45} \mathrm{~A}$ tervek szerint 1996-ban befejezni kívánt feladat több mint háromévnyi késéssel, 2000 júniusában fejeződött be. A Budapesti Ingatlan-nyilvántartási Információs Rendszer (BIIR) kiépítésének pénzügyi hátterét szintén a PHAREsegélyprogram biztosította. ${ }^{46}$

1997. év végére megtörtént a tulajdoni lapok adatainak rögzítése az adatbázisokba a Földmérési és Távérzékelési Intézet által kifejlesztett KDIR (Komplex Decentrális

1994. évi V. törvény 50. \$.

Fenyö - Hidvéginé Erdélyi - Papp i. m. (1. lj.) 32.

Niklasz László: A „földhivatalok számítógépesítése” c. PHARE-projekt — TAKAROS, a digitális kataszteri térképek nyilvántartásának és kezelésének földhivatali koncepciója. Geodézia és Kartográfia, 46. (1995), 2. 90-93.

46 Berczi Norbert: Tájékoztató a földügyi szakág fejlesztési elképzeléseiről. Geodézia és Kartográfia, 55. (2003), 9. 6-11. 
Ingatlan-nyilvántartási Rendszer) szoftver segítségével. ${ }^{47}$ Ezzel egyidőben befejeződött a TAKAROS (Térképen Alapuló KAtaszteri Rendszer Országos Számítógépesítése) rendszer tesztelése is, amely lefedi a körzeti földhivatalok teljes tevékenységét, ügymenetét, az ügyirat-érkeztetéstől, a széljegyzésen, az iktatáson, szignáláson, ügyintézésen, a tulajdoni lapon történő átvezetésen, a tulajdoni lap másolat szolgáltatáson, az irattározáson át a küldemények és a hozzájuk tartozó tértivevények címzéséig. A program támogatja és ellenőrzi a dolgozók munkáját, és különböző leválogatásokat, illetve statisztikai adatszolgáltatást is lehetővé tesz. ${ }^{48}$

A modern ingatlan-nyilvántartási rendszer számítástechnikai feltételeinek megteremtésével egyidejűleg megkezdődött az ingatlan-nyilvántartási szabályozás felülvizsgálata. Ezt indokolták a rendszerváltást követően bekövetkezett jogszabályváltozások, a privatizáció során átalakult jogintézmények, egyes jogterületek (mint a zálogjog) újraszabályozása, ezenkívül a szabályozási tárgyak bővítését célzó igények is megjelentek. ${ }^{49}$ Ezen igények kielégítése céljából született meg az ingatlan-nyilvántartásról szóló 1997. évi CXLI. törvény, valamint az ingatlan-nyilvántartásról szóló 1997. évi CXLI. törvény végrehajtásáról rendelkező 109/1999. (XII. 29.) FVM rendelet. A törvény az elektronikus ingatlan-nyilvántartás elvén állva szabályozza az adatbázishoz csatlakozás feltételeit, az adatlekérdezést vagy az iratbetekintést (amely a legújabb módosításoknak köszönhetően bizonyos esetekben elektronikus úton is megtörténhet).

$\mathrm{Az}$ újabb jelentős lépés az ingatlan-nyilvántartási eljárások elektronikussá tétele kapcsán a TAKARNET (TAKAROS NETwork) -rendszer kiépítése volt, amelynek tervezése 1996-ban kezdődött. A rendszer lehetővé teszi a földhivatali adatok országos elérését egymás és külső felhasználók számára is. A 2003. január 1-jétől igénybe vehető fejlesztéssel vált lehetővé, hogy az állampolgárok az ország bármely ingatlanáról adatokhoz juthassanak anélkül, hogy az illetékes földhivatal székhelyére kellene utazniuk. Így az ingatlanokkal kapcsolatos jogügyletek gyorsabbá és biztonságosabbá váltak azáltal, hogy a hozzáférési jogosultsággal rendelkező ügyvéd a TAKARNET-rendszeren keresztül lekérheti az ingatlan tulajdoni lapját, így naprakész információk alapján készítheti el a szerződést. A rendszer 2005-től képessé vált térképmásolat-szolgáltatásra is.

A TAKARNET-rendszer egyik komoly hiányossága volt, hogy az ingatlanok adatainak lekérdezése bizonyos esetekben nem vezetett eredményre. Ez akkor fordult elö, ha a decentralizált struktúrában működő földhivatali adatbázis nem volt elérhető, például hálózati hiba vagy a szerver leállása miatt. Az adatszolgáltatás kezdetben főként a hivatali munkaidőben volt garantálható, de technikai problémák felmerülése esetén, a szolgáltatás kiesésekor a kéréseket a rendszer nem tudta teljesíteni. Erre a problémára nyújtott megoldást az Elektronikus Közigazgatás Operatív Program (EKOP) kiemelt projektjei

Szabó Béla - Weninger Zoltán: Befejeződött a TAKAROS és a TAKARNET információ-technológiai rendszer országos telepítése. Geodézia és Kartográfia, 52. (2000), 8. 34-38.

48 Csernok Nándor: Nulladik születésnap amit csendben (sem) ünnepeltünk meg. (avagy egy projekt alulnézetből). Geodézia és Kartográfia, 50. (1998), 7. 30-37.

49 Fenyő - Hidvéginé Erdélyi - Papp i. m. (1. lj.) 32. 
közé sorolt Digitális Földhivatal koncepció keretében megvalósított „Földhivatali Adatok Elektronikus Non-stop Szolgáltató Rendszere Ügyfélkapun Keresztül” elnevezésű projekt (TakarNet24 projekt). A TakarNet24 projekt célja, ahogy az elnevezése is mutatja a földhivatali adatok szolgáltatásának kiterjesztése oly módon, hogy a nap 24 órájában, a hét minden napján elérhető legyen bárki számára. A Földhivatal Online rendszer az ügyfélkapun keresztül érhető el, újabb fejlesztéseinek köszönhetően ingyenes szolgáltatásokat (évente kettő tulajdoni lap másolat, illetve $20 \mathrm{db}$ adatszolgáltatás a tulajdoni lap I. része tekintetében) is nyújt, és lehetőség van helyrajzi szám vagy az ingatlan címe alapján tulajdoni lap és térképmásolat lekérdezésére, a korábban lekérdezett dokumentumoknak a tárhelyen, 10 hónapig tartó időszakra történő megörzésére, az iktatószám ismeretében ingatlant érintő ügy állapotának megtekintésére és a díjköteles szolgáltatás igénybevétele esetén a szolgáltatás díjának elektronikus fizetési rendszeren keresztüli kiegyenlítésére.

A rendszer bevezetése az addigi decentralizáltan müködő adatbázisok egységesítésének végrehajtását igényelte. Ennek érdekében a Budapest Főváros Kormányhivatala Földmérési, Távérzékelési és Földhivatali Főosztálynál (FÖMI) központi szerverszobát alakítottak ki, amelyen egységes szerkezetü központi adatbázist hoztak létre. Az adatbázisnak képessé kellett válni a többféle eltérő adatbázis (mint a BIIR és a TAKAROS, vagy a földmérési szakterületen a tulajdonlapi adatkezelés területén tapasztalt különbséghez hasonlóan különböző fővárosi és vidéki adatbázisok: a TOPOBASE és a DATR) adatainak fogadására. A maximális adatbiztonság érdekében az adatbázist adatreplikációs eljárás útján továbbítják a felhasználók felé. Így, amellett, hogy a rendszerből szolgáltatott adatok naprakészek, azok egy esetleges meghamisítás vagy rendszerhiba miatti megváltozás esetén sem befolyásolják az eredeti adatokat, illetve azok helyességét. Ahhoz, hogy az egyesítés a lehető legteljesebb legyen, az adatbázisokat átvizsgálták, és megtörtént a kódharmonizáció és -tisztítás. ${ }^{50}$

\section{AZ INGATLANOK NYILVÁNTARTÁSÁNAK ELEKTRONIZÁLÁSA}

A földművelésügyi hatósági és igazgatási feladatokat ellátó szervek kijelöléséről szóló 383/2016. (XII. 2.) Korm. rendelet alapján jelenleg a földügyi igazgatáshoz tartozó eljárásokat az elmúlt évtizedekben kialakult módon, hagyományosan papíralapon intézik az ingatlanügyi hatóságok. Az eljárásokat támogató informatikai rendszerek elavultak, az elektronikus ügyintézés jelenlegi szabályainak már nem tudnak megfelelni, ezért a Kormány a Közigazgatás- és Közszolgáltatás-fejlesztés Operatív Program éves fejlesztési keretének megállapításáról szóló 1004/2016. (I. 18.) számú határozatában egyetértett azzal, hogy ezek fejlesztése megvalósuljon, méghozzá a KÖFOP-1.0.0-VEKOP-15 azonosító számú, „E-ingatlan-nyilvántartás” címü projekt (eING projekt) végrehajtásával.

50 Szilvay Gergely: TAKARNET24 szolgáltatásai. GISopen konferencia előadás, 2011. Elérhető: www.foldhivatal. hu/images/TakarNet24/gis-open_tk24_szig_2011.pdf (A letöltés dátuma: 2020.05. 05.) 
Az ingatlan-nyilvántartási, térképészeti, telekalakítási feladatok fejlesztése kiemelkedő közigazgatási jelentőségű terület. Az ingatlan-nyilvántartás által közvetlenül érintett ingatlanügyletek, mezőgazdaság és építőipar ágazatok együttesen a nemzetgazdasági teljesítmény körülbelül egyhatodát állítják elő. A jelzálogértékeket is figyelembe véve, a földés ingatlanvagyon a nemzeti vagyon 60-65\%-át adja. ${ }^{51}$ Ennek megfelelően az ingatlanügyi és telekalakítási, valamint mezőgazdasági igazgatási ágazathoz tartozó földügyi hatósági eljárások közigazgatási jelentősége kiemelkedő Magyarországon. ${ }^{52}$ 2018-ban elsőfokú hatóságként 3,3 millió darab ingatlan-nyilvántartási, földügyi eljárás indult, amelyből több mint 2 millió db ingatlan-nyilvántartási ügy (tehát tulajdoni lapra történő adat átvezetése, jogok, tények be-, illetve feljegyzése) volt, amelynek több mint 25\%-a tulajdonjog bejegyzése iránti kérelem. 2018. január 1. és május 31. között összesen 923648 ügy indult az ingatlanügyi hatóságoknál országos szinten, ebböl mindössze 21589 ügy alapult elektronikus úton megküldött beadványon, amely utóbbiból mindössze 2903 db volt a nem végrehajtóktól érkezett kérelem alapján indult elektronikus ügy. ${ }^{53}$ Ehhez a viszonylag alacsony számhoz képest 2019. év második félévében az országos szinten lefolytatott 745218 ingatlan-nyilvántartási eljárásból már 211185 elektronikus úton benyújtott kérelem alapján indult, azaz megtízszereződött az ilyen típusú eljárások száma. ${ }^{54}$

A jelenlegi eljárások ügyintézési határideje meglehetősen hosszú, amelynek egyik oka, hogy a kérelmek benyújtása nagyrészt papíralapon történik, másrészt az eljárási díjak befizetése jellemzően a földhivatali ügyfélszolgálatok pénztárában történik, online fizetésre kevés lehetőség van.

A nemzeti adatvagyon körébe tartozó, földügyi hatóságok által kezelt közérdekű adatok, személyes adatok és közérdekből nyilvános adatok összességét informatikailag elavult, egymással nehezen vagy nem, külső szakrendszerekkel alig kommunikáló, vidéken és Budapesten eltérő, nem egységes földügyi szakrendszerek kezelik. A rendszerek karbantartása és fejlesztése duplikált feladatot és költséget eredményez a magyar állam számára.

51 Méhes Tamás: Birtokpolitika - A földszerzés elmélete és gyakorlata. Acta Humana, 5. (2017), 3. 47-69.

52 Műszaki leírás az elektronikus ingatlan-nyilvántartás létrehozása érdekében infrastruktúra-felmérési, valamint adatbázis- és alkalmazásfejlesztési feladatok ellátása tárgyú közbeszerzési eljáráshoz. Lechner Tudásközpont Területi, Építészeti és Informatikai Nonprofit Kft. 5. Elérhető: http://lechnerkozpont.hu/doc/kozbeszerzes/ elektronikus-ingatlan-nyilvantartas-kozbeszerzes/muszaki-leiras-2018s-072-159701-20180413.pdf (A letöltés dátuma: 2020. 05. 05.)

53 Tóth Balázs: Elektronikus ügyintézés az ingatlan-nyilvántartásban. II. e-Cégkapu Konferencia, 2018. december 11-én tartott előadás.

54 Miniszterelnökség: Elektronikus ügyiratforgalmi statisztika. Elektronikus ügyintézés az ingatlan-nyilvántartásban 2019. II. félév. 


\subsection{Az ingatlan-nyilvántartás felülvizsgálatának időszerüsége}

\subsubsection{A földügyi igazgatás szerkezete}

A földügyi szakigazgatás a gazdasági élet, a mezőgazdaság és hitelforgalom alapjának egyik legnagyobb összetevőjével, a termőfölddel és az ingatlanokkal kapcsolatos, az ország teljes közigazgatási területére kiterjedő, komplex állami adathalmazt jelenti. A földművelésügyi hatósági és igazgatási feladatokat ellátó szervek kijelöléséről szóló 383/2016. (XII. 2) Korm. rendelet alapján jelenleg a földügyi igazgatáshoz tartozik az ingatlan-nyilvántartás, a földhasználati nyilvántartás, a földművesekről, a mezőgazdasági termelőszervezetekről és a mezőgazdasági üzemközpontokról vezetett nyilvántartás (földműves-nyilvántartás), a földmérési és térképészeti állami alapfeladatokkal és alapmunkákkal - ide nem értve a honvédelmi célú földmérési és térképészeti tevékenységet - a földméréssel, a térképészettel, a távérzékeléssel, a térinformatikai rendszerek müködtetésével és az államhatárral kapcsolatos nemzetközi kötelezettségek, továbbá a földminősítéssel, a földvédelemmel, a földhasznosítási előírások érvényesülésével, a földtulajdoni és a földhasználati előírások érvényesülésével, a földforgalommal és a telekalakítással kapcsolatos tevékenységek, hatósági feladatok és adatbázisok.

A földügyi igazgatás fenti feladatai részben a Miniszterelnökséget vezető miniszter, részben az agrárminiszter szakmai irányítása alá tartoznak. Annak érdekében, hogy a szakmailag együtt kezelendő tevékenységek egymással koherensek legyenek, a két miniszter egymással együttműködésben látja el a feladatait. A földügyi igazgatáshoz kapcsolódó hatósági és informatikai üzemeltetési feladatokat jelenleg a fövárosi és megyei kormányhivatalok mint ingatlanügyi hatóságok, valamint a Lechner Tudásközpont mint földmérési és térinformatikai államigazgatási szerv látják el.

\subsubsection{A földügyi igazgatás célja}

A földügyi igazgatás célja a tulajdonhoz, az egészséges környezethez való jog, a vállalkozás és a gazdasági verseny szabadságához való jog érvényesülésének támogatása, a természetes és mesterséges tereptárgyak hiteles nyilvántartása az egységes és közhiteles ingatlan-nyilvántartási és tér-adat infrastruktúra biztosítása révén. Ezen belül is az ingatlan-nyilvántartás célja az ingatlan adatainak, a jogszabályban meghatározott releváns jogok és a törvényben meghatározott jogilag jelentős tények közhiteles nyilvántartásának vezetése, illetve az abból történő adatszolgáltatás annak érdekében, hogy a Magyar Állam e közhiteles nyilvántartással garantálja az ingatlanforgalom biztonságát, valamint segítse a Kormányt nemzetgazdasági céljainak elérésében. 


\section{AZ EING PROJEKT BEMUTATÁSA}

\subsection{Az eING projekt szükségességének okai}

Noha az ingatlan-nyilvántartás története alapján elmondható, hogy az elmúlt 170 évben az ingatlan-nyilvántartás folyamatos fejlesztése mindig kiemelt államigazgatási cél volt, és eredményei elvitathatatlanok, az elmúlt három évtized információtechnológiai fejlődése óhatatlanul elavulttá tette a jelenleg használatos informatikai rendszereket. Ennek negatív hozadéka nemcsak az ingatlan-nyilvántartással közvetlenül kapcsolatba kerülö ügyfelekre és az ingatlanügyi hatóságokra, hanem más hatóságokra, bíróságokra, a gazdasági élet egyéb szereplőire is kihatással van. Az eljárások lefolytatása papíralapon történik (még annak ellenére is, hogy az ingatlanügyi hatósághoz 2019. második félévében a benyújtás 28\%-a már elektronikusan, biztonságos kézbesítési szolgáltatáson keresztül történt), más nyilvántartásokkal kialakított online kapcsolat nem vagy nagy nehézségek árán üzemel, az általános közigazgatási rendtartásról szóló 2016. évi CL. törvény (Ákr.) szerinti automatikus döntéshozatalra egyáltalán nincs lehetőség. Az adatszolgáltatás során nyújtható adatok formátuma nem mindig elégíti ki a jogos ügyféligényeket. Az informatikai rendszerek széttagoltak és elavultak, ugyan a jelenlegi földügyi igazgatáshoz tartozó eljárásokhoz megfelelnek és stabilak, de ezek 25 éves technológiákon alapulnak.

Az eING projekt indítása előtt számos probléma megoldása vált szükségessé. Az ingatlannyilvántartási informatikai rendszer elavult: a hardver/szoftver architektúra korszerütlen, a rendszer fejlesztése pedig 25 éves technológiára épül, amivel alkalmatlan a kor kihívásainak teljesítésére, és biztonsági kockázatokat is rejt. Történelmi okokból az ingatlannyilvántartási rendszer nem egy egységes informatikai rendszer, hanem 119 járási (a korábbi körzeti földhivatali) rendszer összessége. További probléma, hogy a 117 vidéki rendszer ugyanolyan, azonban a két fővárosi rendszer ettől különböző, mind az ingatlannyilvántartási, mind a térképi modul tekintetében. Az ingatlan-nyilvántartás közhiteles adatbázis, így alapvető elvárás lenne, hogy a benne a tárolt adatok pontosak, naprakészek legyenek. Ez azonban több aspektusból nem teljesül. A személyhez, céghez, szervezethez köthető azonosítási adatok hiányosak, nem pontosak. A tulajdoni lapon szereplö leíró adatokat meghatározó úgynevezett kódszótárak (annak ellenére, hogy a korábban írtak szerint a TAKARNET24 rendszernél a FÖMI elvégezte a szükséges kódharmonizációt) nem egységesek a 119 adatbázisban, így az adatszolgáltatás pontatlan, lassú. Az ingatlannyilvántartási térképek sok esetben nem felelnek meg a valóságnak.

$\mathrm{Az}$ ingatlan-nyilvántartási folyamatok kizárólag papíralapon müködnek, így nem teljesül az elektronikus ügyintézés megvalósítását kitűző cél. A közigazgatás hatékony müködése szempontjából fontos cél, hogy az alapnyilvántartások elérhetők legyenek egymás számára elektronikus úton. A jelenlegi ingatlan-nyilvántartás sem adatot fogadni, sem adni nem képes a közigazgatási eljárások során a fogadó oldal számára feldolgozható formában. Egyetlen kivétel a Központi Címregiszter, ahol a címnyilvántartást összekötötték a személyiadat- és lakcímnyilvántartással és az ingatlan-nyilvántartással. A jelenlegi környezet több törvény, rendelet, határozat és utasítás szabályozása alatt áll, így szükséges ezek 
egységesítése, konszolidáció a jogalkotásban. További nehézség, hogy más szakigazgatási ágazatok esetén lehetőség van a hivatalból indított eljárások lefolytatására, ami szükséges lenne az ingatlan-nyilvántartási eljárásban is, de ezt a jelenlegi jogszabályok nem teszik lehetővé. A hatályos szabályozás alapján ingatlant érintően ügy jelenleg csak az ingatlan fekvése szerinti illetékes kormányhivatalban intézhető. A jogszabályi környezet, az elavult rendszer és a betöltetlen ügyintézői állások miatt egy ügy intézésének időtartama jelentősen megnött.

Mindezekre tekintettel a Kormány a Közigazgatás- és Közszolgáltatás-fejlesztés Operatív Program éves fejlesztési keretének megállapításáról szóló 1004/2016. (I. 18.) Korm. határozatában akként döntött, hogy a Lechner Tudásközpont Nonprofit Kft. (LTK) mint földmérési és térinformatikai államigazgatási szerv konzorciumvezetésével olyan projektet folytathat le, amelynek célja nemcsak az ingatlan-nyilvántartási eljárások, hanem a földügyi igazgatáshoz tartozó valamennyi hatósági eljárás és adatszolgáltatás elektronikus alapokra helyezése az informatikai rendszerek és a jogszabályi környezet fejlesztésével.

\subsection{Az eING projekt célja}

Az eING projekt indulásakor, 2016-ban a Földmüvelésügyi Minisztérium a FÖMI-vel együttműködve a következő célok elérését fogalmazta meg. A földügyi ágazat valamennyi nyilvántartó informatikai szakrendszerének (beleértve az ingatlan-nyilvántartást, a térképi, földhasználati, földműves nyilvántartást és az ezekhez kapcsolódó megyei és vezetői rendszereket) egységesítését, az így létrejövő szakrendszer fejlesztését. Ezen belül front office rendszer létrehozását, amely az ügyfelek számára elérhető (e-űrlapok, nyomtatványkitöltő programok) és back office rendszer létrehozását, amely az ügyintézők számára nyújt segítséget az ügyintézésben (iktatás, változásvezetés a tulajdoni lapon, térképen, földhasználati lapon). A kezdeti célok között szerepelt továbbá az elektronikus ügyintézés bevezetése valamennyi földügyi ágazatot érintő eljárásban, a háromdimenziós ingatlan-nyilvántartás bevezetése és a papíralapú okirattár digitális átalakítása. Az eING projekt a fentiek alapján a legnagyobb mértékű változást az ingatlan-nyilvántartásban hozza, amely jelentős ügyintézési tehercsökkenést idéz elő mind az ügyfelek, mind pedig az ingatlanügyi hatóságok számára. A fenti feladatok gyökeresen megváltoztatják a földügyi ágazatra vonatkozó eljárásokat, így az ingatlan-nyilvántartási szakterület közigazgatási eljárásait is. A kezdeti elgondolás szerint a fejlesztések eredményeként mind jogi, mind pedig műszaki informatikai oldalról lehetővé vált volna az elektronikus ügyintézés, illetve az ingatlan-nyilvántartási adatszolgáltatás. Az eiNG projekt kezdeti céljai között szerepelt a térbeli nyilvántartás kialakítása is, amely az elektronikus ügyintézés mellett a másik szakmailag jelentős, kihívást igénylő feladat. ${ }^{55} \mathrm{Az}$ eING projekt megvalósítását elsősorban nem a szakmai igények, de még csak nem is a 21. századi szolgáltatások nyújtásának eszméje vezérelte, hanem

5 Varga Márk: A 2015. év margójára. Geodézia és Kartográfia, 68. (2016), 3-4. 4-6. 
az a tény is, hogy 2018. január 1-jétől valamennyi közigazgatási eljárást elektronikusan kell lefolytatni. ${ }^{56}$

Az eING projekt célja az ingatlan-nyilvántartás és az állami térképi nyilvántartást vezető informatikai környezet összehangolása a föváros és vidék esetén, ezen integráció biztosítása nélkül a projekt megvalósítása nem lehetséges (szoftver és alapadatok, a földügyi szakigazgatás által jelenleg is használt TAKAROS ingatlan-nyilvántartási információs rendszer, Budapesti Ingatlan-nyilvántartási Információs Rendszer, Digitális Alaptérképen alapuló Térképkezelő Rendszer, Topobase szoftver egységesítése).

Az egységes rendszer és egységes alapadatok biztosítják továbbá a kormányzati nyilvántartásokkal való összekapcsolódást (interoperabilitás), így megvalósul a kapcsolódó nyilvántartások földügyi adatokkal történő kiszolgálása is. Az eING projekt keretében megvalósuló fejlesztések célja az elektronikus ügyintézés kiterjesztése az ingatlan-nyilvántartási eljárásokban, a földügyi informatikai rendszerek szolgáltató képességének növelése, a földügyi eljárások új, munkafolyamat-támogató e-megoldásainak kialakítása és a földügyi adatbázisok konszolidációja. Az eING projekt további, horizontális (minden „beavatkozási területre” és fejlesztési tevékenységre kiterjedő) célja, alapkövetelménye, megfelelve a KÖFOP-felhívás által meghatározott „horizontális követelményeknek”, az „esélyegyenlöség és környezeti fenntarthatóság előmozdítása”. ${ }^{57}$

Az ingatlanokat érintően számos nyilvántartási szakrendszer működik önállóan. A szakrendszerek önállóságát nem érintve, a most kezdődő fejlesztéssel az ingatlan-nyilvántartási eljárásokat, illetve az ingatlan-nyilvántartásból történő adatszolgáltatást támogató informatikai rendszerek, a földmérési, térképészeti és telekalakítási eljárásokat és az adatszolgáltatást támogató informatikai rendszer, a földhasználati nyilvántartást és az abból történő adatszolgáltatást támogató rendszer, a földmüves nyilvántartás, a földtulajdoni és földhasználati szabályok érvényesülésének betartásával foglalkozó eljárásokat támogató informatikai rendszer, valamint a földminősítési eljárásokat támogató informatikai rendszer és az azok segítségével lezajló eljárások és adatszolgáltatások válhatnak elektronikussá.

$\mathrm{Az}$ eING projekt sikeres végrehajtásával a földügyi igazgatás tevékenysége teljes mértékben koherenssé válik az általános közigazgatási rendtartásról, a perrendtartásokról, valamint az elektronikus ügyintézésről szóló ágazati szabályozásban megkövetelt rendelkezésekkel. Kialakíthatók az online adatkapcsolatok más informatikai rendszerekkel, nyilvántartásokkal, adatbázisokkal, könnyebbé válna a földmérő vállalkozók, a földmüvesek, a jogi képviselők, bíróságok, hatóságok munkája. Új elemként a fejlesztés lehetővé teszi, hogy szintben eltérő objektumok (alul- és felüljárók, csatornák, pincék, alagutak, hidak stb.)

56 Boros Anita - Vincze-Csapó Emese - Jugovits Károly: Az alapeljárási szabályok szabályozási karakterisztikája (1957-2018). In Boros Anita - Patyi András (szerk.): A hazai közigazgatási hatósági eljárási jog karakterisztikája. Budapest, Dialóg Campus, 2019. 135-196. 172.

57 Müszaki leírás az elektronikus ingatlan-nyilvántartás létrehozása érdekében infrastruktúra-felmérési, valamint adatbázis- és alkalmazásfejlesztési feladatok ellátása tárgyú közbeszerzési eljáráshoz. Lechner Tudásközpont Területi, Építészeti és Informatikai Nonprofit Kft. Elérhető: http://lechnerkozpont.hu/doc/kozbeszerzes/ elektronikus-ingatlan-nyilvantartas-kozbeszerzes/muszaki-leiras-2018s-072-159701-20180413.pdf (A letöltés dátuma: 2020. 05. 05.) 
is feltüntethetők legyenek az ingatlan-nyilvántartásban, ezáltal ezen „új” ingatlankategória a jelzálogpiac lehetőségeit is bővítené. ${ }^{58}$

\subsection{A földïgyi igazgatási eljárások felülvizsgálata}

Annak érdekében, hogy a jogos ügyfélelvárásoknak, valamint a KÖFOP által meghatározott kereteknek az eING projekt teljes mértékben megfeleljen, nemcsak informatikai fejlesztésre, hanem a szakterületet szabályozó anyagi és eljárásjogi szabályozás felülvizsgálatára is szükség van. Egyfelől azért, hogy az elektronikus ügyintézés hatályban lévő szabályozásával teljes koherenciát mutassanak az ágazati rendelkezések, másfelől azért, mert az új rendszer kibővített funkciói szükségtelenné vagy átalakíthatóvá tehetnek olyan eljárásokat, eljárási módokat vagy eljárási lépéseket, amelyek a mostani tevékenységek szerves részét képezik.

Az ingatlan-nyilvántartás reformja kapcsán két, egymással részben átfedéseket mutató megoldás különíthető el.

\subsubsection{Az ingatlan-nyilvántartás átfogó reformja}

Egyik alternatíva alapján különösen az ingatlan-nyilvántartás (ezen belül is az adatváltozás-átvezetés, illetve a jogok, tények bejegyzése, feljegyzése) és egyes földforgalmi ügyek vonatkozásában a jelenlegi dogmatikai rendszert átalakító, átfogó reformot hajtanának végre. A jelenlegi alapelvek ugyanis túlhaladottak lehetnek, illetve a szabályozás sem minden esetben felel meg az alapvető dogmatikai és kodifikációs kívánalmaknak. Ezenfelül nemcsak az egyes hatósági intézkedéseken alapuló eljárásokban és bejegyzéseknél, hanem a természetes és jogi személyek egymás közötti jogügyleteinél is ki kellene iktatni a humán erőforrás igénybevételével járó hatósági tevékenységet úgy, hogy azzal az ingatlanügyi hatóságokról a bejegyzés felelősségét a jogi képviselőkre (ügyvédekre, jogtanácsosokra) kellene telepíteni. Ezzel összefüggésben az elsőfokú eljárások tekintetében minél szélesebb körben lehetővé kell tenni az Ákr. szerinti automatikus döntéshozatalt. ${ }^{59}$ Az automatikus döntéshozatal föszabály szerint a kérelmen alapul, a mellé csatolt okiratot sem a rendszer, sem a hatóság nem vizsgálná. Minden olyan esetben, amelyben nem lehetséges az automatikus döntéshozatal, a kérelmet külön eljárásban bírálnák el.

$\mathrm{Az}$ automatikus döntéshozatal és az elektronikus eljárás sajátosságaira figyelemmel az elektronikus rendszer felhasználóinak (jogi képviselő, hatóságok, bankok, bíróságok, végrehajtók stb.) felelősségi körét bővíteni szükséges, de olyan védelmi mechanizmusok

58 Müszaki leírás az elektronikus ingatlan-nyilvántartás létrehozása érdekében infrastruktúra-felmérési, valamint adatbázis- és alkalmazásfejlesztési feladatok ellátása tárgyú közbeszerzési eljáráshoz. i. m. (57. lj.)

59 Boros Anita - Pollák Kitti: A hatóság döntései. In. Boros Anita - Darák Péter (szerk.): Az általános közigazgatási rendtartás szabályai. Budapest, Nemzeti Közszolgálati Egyetem, 2019. 163. 
beépítése mellett, hogy biztosítva legyen a nyilvántartások közhitelessége és az állampolgárok jogainak megfelelő védelme. A fejlesztéssel létrejövő elektronikus rendszerekhez hozzáférő jogosultakat az egyes rendszerekhez, nyilvántartásokhoz igazodóan szükséges rögzíteni, illetve meghatározni akként, hogy a rendszer ellenőrizni tudja a hozzáférési jogosultság érvényességét. Az új elektronikus rendszerben biztosítani szükséges, hogy a bíróságok, hatóságok, illetve a jogi képviselök az automatikus döntéshozatallal érintett ügyekben eljárhassanak.

A Polgári Törvénykönyvről szóló 2013. évi V. törvény írásbeliségre vonatkozó szabályait szükséges felülvizsgálni, illetve kiegészíteni akként, hogy az ingatlan-nyilvántartási, térképészeti, telekalakítási feladatokat támogató informatikai rendszer elektronikus ügyintézési felületén megtett nyilatkozatok írásbelinek minősüljenek. Szükséges annak vizsgálata is, hogy az így tett nyilatkozatok a polgári perrendtartásról szóló 2016. évi CXXX. törvény alapján folyó eljárásokban milyen bizonyító erővel rendelkezzenek, biztosítva azt, hogy amennyiben egy személy jognyilatkozatot tesz teljes körü azonosítást követően az elektronikus ügyintézési felületen, az megfelelö bizonyító erővel rendelkezzen. Emellett az új elektronikus rendszernek képessé kell válnia arra, hogy automatikusan - lényegében azonnal - értesítse az ingatlan tulajdonosát, amennyiben az ingatlanára bejegyzés történt vagy lekérték az ingatlan adatait. Ez megvalósulhat az ügyfélkapun keresztül és/vagy akár mobilapplikáció használatával, online módon.

Az elektronikus ügyintézés ezen magas szintjét valósítja meg az osztrák telekkönyvi nyilvántartás. Ausztriában a telekkönyvi eljárások mintegy 60\%-a elektronikus úton benyújtott kérelemre indul, tekintettel arra, hogy a közjegyzők, ügyvédek, pénzintézetek kizárólag ebben a formában nyújthatják be a beadványokat. Az elektronikus kérelmekből a szükséges adatok könnyen átemelhetők a telekkönyvbe, ezért a bejegyzés alapjául szolgáló okiratokat egyszerü formátumú elektronikus dokumentumként (PDF) nyújtják be a kérelmezők. Az elektronikus telekkönyvi eljárás a kérelem beérkezésétől, a döntéshozatallal együtt zajló telekkönyvi bejegyzésen és annak ellenőrzésén át, a döntés elektronikus úton történő kézbesítéséig tart. Az eljárás időszükségletét nagymértékben csökkenti, hogy ez utóbbi a döntéshozatallal egyidőben szintén automatikusan történik felgyorsítva a telekkönyvi bíróság és a kérelmezők közötti kommunikációt. ${ }^{60}$

\subsubsection{Az ingatlan-nyilvántartás digitalizációs reformja}

Az ingatlan-nyilvántartás átalakításának második alternatívája alapján pedig - az ingatlannyilvántartás alapvető átalakításának sok alapvetésével egyetértve - a jelenlegi alapvető dogmatika fundamentumán, azokat esetlegesen csak a legszükségesebb mértékben módosítva kell az ingatlan-nyilvántartást és a földügyi igazgatást fejleszteni.

60 Hajdu Tádé Miklós - Jánossy András: Magyar szemmel az osztrák ingatlan-nyilvántartásról. Geodézia és Kartográfia, 69. (2017), 4. 22-23. 
A digitalizációs reform - összhangban az eING projekttel - értelemszerüen itt is kiterjed az elektronikus ügyintézés minden aspektusára. Ennek megfelelően koherenssé válik az elektronikus ügyintézés és bizalmi szolgáltatások általános szabályairól szól 2015. évi CCXXII. törvény (Eüsztv.), valamint annak végrehajtási rendeletébe foglalt, földügyi igazgatásra is kiterjedő szabályozásával. Az új informatikai rendszer adottságaira tekintettel a hatósági és bírósági eljárásokban már bevezetett ügyfél-azonosítás, ügyiratkezelés és -továbbítás, más, elsődleges információforrásoknak minősülő nyilvántartásokkal való kapcsolat, a földügyi igazgatáshoz tartozó eljárások szempontjából releváns központi elektronikus ügyintézési szolgáltatások használata megvalósul. A kifejlesztendő elektronikus ürlap alkalmazásával egyszerüsödhet a beadványszerkesztés és -benyújtás. A reform eredményeként a földügyi igazgatás eljárásai, kezelt nyilvántartásai és adatbázisai a kor színvonalának megfelelően magas minőségűvé válnak információbiztonsági szempontból. A digitalizációs reform során szempont, hogy az informatikai rendszer rugalmasan tudja kezelni valamennyi jogosultság-hozzáférést, ügytípust annak érdekében, hogy a jövőbeni anyagi és eljárásjogi szabályváltozások és közigazgatás-szervezési feladatok is optimális idő- és energiaráfordítással megvalósulhassanak. ${ }^{61}$

Mindazonáltal az ingatlan-nyilvántartás teljes szabályrendszerén - ideértve az ingatlannyilvántartás alapvetésein - véleményem szerint nem indokolt változtatni. A mostani kialakult eljárások, bírósági gyakorlatok, valamint a Kúria idevágó, joggyakorlat-elemző munkacsoportjának következtetései alapján az ingatlan-nyilvántartásnak nem a jelenlegi rendszere az alapvető szűk keresztmetszet. Sokkal inkább okoz nehézségeket a papíralapú eljárások kizárólagossága, egyes ingatlan-nyilvántartáshoz kötődő ügyletek nem megfelelő vagy elavult szabályozása - eklatáns példa erre a földnek nem minősülő ingatlanok esetében az elővásárlási jog szabályozása, ellenőrzése, valamint a társasházak alapításával vagy azok alapító okiratának módosításával kapcsolatos szabályozás -, valamint az ingatlan-nyilvántartásból történő adatszolgáltatások nehézkessége. ${ }^{62}$ E problémák azonban meglátásom szerint anélkül is javíthatók, hogy az ingatlan-nyilvántartás alapvető és teljes átalakítása megtörténne.

Így az okirat elve, illetve az okiraton alapuló bejegyzés lenne továbbra is az ingatlannyilvántartás alapja, és az egyes eljárásokban az automatikus döntéshozatal nem járna a jogi képviselők felelősségének kiterjesztésével, állami hatósági kontroll nélküli bejegyzés lehetőségével.

Ezzel a megoldással lehetővé válna, hogy az ingatlanügyi hatósághoz a jövőben ne kelljen papíralapú okiratokat benyújtani, hiszen az Eüsztv., valamint az ügyvédi tevékenységről szóló törvény lehetőséget teremtene arra, hogy mind a kérelem, mind pedig a bejegyzés alapjául szolgáló okiratokat és egyéb igazolásokat elektronikusan nyújthassák be. Ennek

Müszaki leírás az elektronikus ingatlan-nyilvántartás létrehozása érdekében infrastruktúra-felmérési, valamint adatbázis- és alkalmazásfejlesztési feladatok ellátása tárgyú közbeszerzési eljáráshoz. i. m. (57. lj.)

62 Az Ingatlan-nyilvántartási joggyakorlat-elemzőcsoport összefoglaló véleménye. A Kúria Joggyakorlat-elemző Csoportja, 2016. Elérhető: https://kuria-birosag.hu/sites/default/files/joggyak/az_ingatlan-nyilvantartasi_ joggyakorlat-elemzo_csoport_osszefoglalo_velemenye_1.pdf (A letöltés dátuma: 2020. 04. 23) 
részletszabályai, megoldási lehetőségei nem kívánják az ingatlan-nyilvántartás teljes átalakítását vagy az ingatlanügyi hatóságon keresztül megvalósított állami kontroll elvesztését. A digitalizációs reform lehetőséget adhat arra is, hogy azokat a hatóságok, illetve bíróságok által benyújtott beadványokat, ahol az ingatlanügyi hatóság regisztrációs szervként csak kvázi deklaratív módon a döntések átvezetését, bejegyzését végzi, automatikus döntéshozatali eljárással folytathassák le.

\section{4. ÖSSZEGZÉS}

A kétféle reformötlet megvalósíthatósága kapcsán véleményem szerint kijelenthető, hogy a földügyi igazgatás fejlesztése elodázhatatlan, azonban jelenleg az ingatlan-nyilvántartási eljárások átalakítására vonatkozó alternatívák közül az ingatlan-nyilvántartás digitalizációs reformja tűnik észszerű, megvalósítható és hosszú távon működőképes megoldásnak és nem az ingatlan-nyilvántartás alapvető átalakításával járó változat. Az elmúlt években az ingatlanügyi hatóságok által tapasztalt ügyféli visszajelzések alapján nem látszik indokoltnak az ingatlan-nyilvántartás alapvető átalakítása. Ezen visszajelzések az egyes hatósági döntések elleni jogorvoslatok száma, azok eredménye, a Kúria joggyakorlatelemző munkacsoportjának következtetései mutatják. Az ingatlan-nyilvántartási eljárás informatikai fejlesztése a mai információtechnológiai szinten nem alkalmas arra, hogy a Ptk.-ban szabályozott egyes alapelveket, eljárási szabályokat maga ellenőrizzen, tartson vagy tartasson be. Az ingatlan-nyilvántartás alapelvei az elmúlt 170 évben lényegében változatlanok maradtak, azok messzemenőkig kiállták az idők próbáját. Az idők során több államberendezkedést, ingatlanügyi hatóságokra vonatkozó, valamint a közigazgatásra vonatkozó átalakítást megéltek, és a jogalkotó minden egyes reform során a megtartásuk vagy minimális változtatásuk mellett döntött. Az eING projekttel létrejövő új informatikai rendszer a digitalizációs reformmal is jelentős lépést tesz előre, olyan 21. századi infrastruktúrát teremt, amely a nemzetgazdaságra is kiemelkedő hatással van, ugyanakkor a rendszer alapvető átalakítása ehhez képest nem mutat jelentős előnyt. Az ingatlan-nyilvántartás teljes átalakításával járó paradigmaváltás előkészítése, végrehajtása, a kodifikáció szétfeszíti az eING projekt anyagi és időkeretét, ezzel a sikeres lezárást veszélyezteti, ami akár visszafizetési kötelezettséggel is járhat az Európai Unió felé. Az ingatlan-nyilvántartás teljes átalakításával járó paradigmaváltás nem látszik időszerünek a világjárványt követő, gazdasági újraindítási feladatok végrehajtásával egy időben. Az ügyfélérdek ilyen időszakban jellemzően az, hogy az ismert eljárásokkal minél egyszerübben és gyorsabban és a jogbiztonság biztosításával lehessen közigazgatási ügyeket intézni, és e célok megvalósítását egy alapjaiban megreformált rendszer nem szolgálhatja.

A földügyi igazgatás egymással szorosan összefüggő, egymásra ható, koherens rendszer; egy részét kiragadni és teljesen átalakítani azzal a veszéllyel járhat, hogy ez az összhang megbomlik, ami káros következményekkel járhat az agrárgazdaságban, illetve azon ágazatokban, amelyeket a térképészet kiszolgál. 
Egyes nemzetközi példák (észt, svéd vizsgálatok és fejlesztések) azt mutatják, hogy az ingatlan-nyilvántartás fejlesztése nem a felelösségi körök áttelepítésével, az alapelvek újraértelmezésével történik, hanem az ingatlanhoz kapcsolódó különböző jogügyletek összekapcsolása (például ingatlanvásárlás állami támogatással, kölcsön felvételével) révén a legújabb információtechnológiai eredmények felhasználásával (ez általában a blockchaintechnológia beépítését jelenti).

A svéd földügyi igazgatási rendszert nemzetközi szinten is biztonságosnak és megbízhatónak tartják, és a polgárok részéről is nagyon erös iránta a bizalom. Az állampolgárok, a bankok és más érdekeltek bíznak a rendszerben, és az állam szavatolja az ingatlanok, a tulajdonosok, az ingatlanokra vonatkozó jogok valósságát és hitelességét, valamint a térképi állapotot; köszönhetően annak, hogy a nyilvántartás évszázadok óta zavartalanul fejlődhetett. Az államilag vezetett térképek és az ingatlan-nyilvántartás hosszú időszaka alatt számos új fejlesztés történt, és új technológiákat dolgoztak ki. Svédországban a digitalizált ingatlan-nyilvántartást az 1970-es években vezették be. A jelzálogokat és az alapjául szolgáló papíralapú okiratokat az 1990-es években digitalizálták. Az elmúlt évek számos informatikai rendszer gyors és kiterjedt fejlesztését hozták, a folyamat közel áll az ingatlannyilvántartás teljes digitalizáltságának állapotához, emellett a svéd ingatlan-nyilvántartást valós időben közzétett, automatizált döntéshozatal jellemzi. ${ }^{63}$

A digitalizált folyamatok nagy része jelenleg még papíralapú információk kezelésén alapuló műveletekből származik. Bár a papír használata világszerte egyre inkább csökken vagy akár megszünik az igazgatási folyamatok egyes részeiben, de még mindig szükséges további lépéseket tenni annak érdekében, hogy megváltozzon a gondolkodásmódunk, és megpróbáljuk nem papíralapon kezelni a dokumentumokat a digitális világban. Az a tény, hogy a digitális világban nehéz megtalálni a megfelelő megoldásokat a tranzakciók biztonságának szavatolására, még mindig szükségessé teszi a bejegyzéshez a papíralapú dokumentumokat. Például az ingatlanvásárlási szerződések, a svéd IOU-k ${ }^{64}$ és sok más aláirást tartalmazó dokumentum még mindig papíron készül. A technikai fejlődés azonban nagy léptekkel halad előre, és az információk kezelésének technikai lehetőségei folyamatosan bővülnek. Az egyik olyan új technológia, amely nagy érdeklődésre tarthat számot, az a blockchain-technológia.

Ma már közismert a digitális valutával, a Bitcoinnal folytatott kereskedelem. Néhány év gyakorlati használat után a pénzügyi szektorban is számos felhasználási területet fedeztek fel a digitális valuták kapcsán. A pénzügyi szolgáltatásokon kívül, úgy tűnik más területek vonatkozásában is, hogy nagy előnyökkel járhat a blockchain-technológia alkalmazása, a földügyi nyilvántartások tűnnek a leginkább alkalmasnak annak implementálására. A Lantmäteriet néhány partnerrel közösen részt vett egy pilot projektben annak érdekében, hogy feltárja és megvizsgálja, hogy a blockchain rendszer megfelelő alternatíva lehet-e az ingatlanügyletek folyamatának támogatására; felváltva a hagyományos számítógépes

63 Mats Snäll: Blockchain and the Land Register - a new "trust machine"? BlockchainExpo Global 2018. London, 2018. április $18-19$.

64 Tartozáselismerő nyilatkozat. 
adatbázisok és a webes alkalmazások rendszerét. A blockchain-technológiának a földügyi igazgatásban való megvalósításához szükség van az elektronikus közvetítés területén dolgozó szakemberek jogi és geodéziai szakértelmére. Az új technikák sok esetben segítséget nyújthatnak a földügyi eljárásokban, amennyiben ez nem veszélyezteti a fékek és ellensúlyok elvét. Ehhez együttmüködésre van szükség minden érintett fél között, akik mindanynyian ösztönzést szeretnének találni az eljárásban. Ez a feszültség, amikor olyan „bomlasztó technológiáról” beszélünk, amelyet azért fejlesztettek ki, hogy bizonyos részt vevő feleket „kiküszöböljenek” a folyamatból. Szükség van e folyamatok hatásainak alapos átgondolására, a megfelelő mértékű gondosságra és a körültekintésre, egyfajta egészséges éberségre. ${ }^{65}$

A blockchainalapú földhivatali rendszer bevezetése esetén nem szabad figyelmen kívül hagyni az adott állam jogrendszerének egészét, ezen belül a dologi jogok alapvető szabályait (így a numerus clausus meglétét vagy annak hiányát), a különböző jogügyletek összetettségét és változatosságát, valamint az eljárásokban kötelező jelleggel bevont szakemberek szerepét az ingatlanok továbbításának láncolatában. A folyamatok (és annak részei) szabványosítása nélkül az ügyek komplexitása a fejlődés sikerességének akadályává válhat.

Grúziában az első földügyi eljárások elektronizálására irányuló pilot projekt biztosította a jogcímek archiválását a blockchainben. A sikeresen zárult pilot célja az volt, hogy megszüntesse a papíralapú ügyintézést, és biztosítsa a jogcímek nyilvántartását a blockchain-rendszerben. A pilot második fázisának középpontjában az intelligens szerződések bevezetése állt. Intelligens szerződések alkalmazásával Grúzia megpróbálta automatizálni a tulajdonátruházás teljes folyamatát. Grúzia és a Bitfury együttműködésével a bitcoin használatát tűzték ki célul, ezért egy „konszenzusmechanizmusra” épülő technikát vezettek be. ${ }^{66}$

A pilot konzekvenciája szerint jó eredményekkel lehetséges a blockchain-technológiát használni az ingatlant érintő jogügyletek nyilvántartásához. Ezzel a meglehetősen új technológiával a tranzakciók tartalmának és a mögöttes ügyletek hitelességének biztosításával az adott tranzakció és magának az átruházó aktus metaadatainak megadásával a végrehajtott tranzakciók története szabotázsbiztossá válhat.

Azokban az országokban, ahol nincs megbízható elektronikus tulajdonátruházási rendszer, ott a blockchain alkalmazása hasznos lehet, bár a hagyományos, papíralapú, számítógépes adatbázisba utólagosan rögzített adatokból felépülő ingatlan-nyilvántartási adatbázisrendszerek hitelessége (biztonsági másolatokkal és naplózással) továbbra is elegendő. Az engedélyezési és hitelesítési lehetőségekkel kiegészítve, ezeknek az adatbázisoknak a tartalmát meg lehet osztani más, a folyamatban részt vevő felekkel is az adatok továbbítása céljából. A meglévő és könnyen elérhető technológia, a jó kormányzati technikákkal kombinálva kielégő módon működhet. Azok az államok, ahol az ingatlanokat

65 Jacob Vos - Christian Lemmen - Bert Beentjes: Blockchain-based Land Administration Feasible, Illusory or a Panace? Responsible Land Governance: Towards an Evidence Based Approach. Washington, D.C.: Annual World Bank Conference on Land and Property, 2017.

66

Snäll i. m. (63. lj.) 
érintő jogügyletekben részes felek hajlandók kockázatot vállalni, megpróbálhatják kiaknázni a blockchain lehetőségeit. Azonban az információtechnológia aktuális helyzete okán egyes államokban ezek az új technológiák még nem alkalmazhatók minden lehetséges helyzetben vagy mindenféle jogügylettípusra.

A másik fontos terület, ahol a Blockchain hasznossága vitán felül áll, az a jogcímek (vagy az ingatlanra vonatkozó jogok) nyilvántartása, például annak bizonyítása érdekében, hogy ki egy adott ingatlan tulajdonosa egy meghatározott időpontban, aki a tulajdonjogát átruházhatja az időbélyeg és minősített elektronikus aláírás kiállítása idején. ${ }^{67}$

Ma minden országnak alapvető érdeke a jól működő, a felhasználói igényeket kiszolgáló földügyigazgatási rendszer (ideértve az ingatlan-nyilvántartást is). Az ingatlanokhoz füződő jogosultságok hitelességének szavatolása a piacgazdaság alapja. Ahogy az a korábban írtakból is kitűnik, Magyarországon az ingatlan-nyilvántartás fejlődése folyamatos volt. Miután hazánkban működő, hiteles ingatlan-nyilvántartási rendszer volt, a kormány kiváló eszközzel rendelkezett a föld- és ingatlanpiac, a földrendezés, a földhasználat és a földvédelem felügyeletéhez, irányításához és befolyásolásához. Az egységes ingatlan-nyilvántartási rendszerbe integrált kataszteri térképek megmutatják a tulajdoni lapokon szereplő jogok, tények és adatok összefüggéseit, ezzel alapot biztosítanak az Unió által is elvárt nemzetgazdasági tervezési feladatok megvalósításához. Az EU INSPIRE irányelvének ${ }^{68}$ megfelelően hazánkban is cél a nemzeti téradat-infrastruktúra kialakítása egyebek mellett a közhiteles ingatlan-nyilvántartási adatokra alapozva. ${ }^{69}$

Kijelenthető, hogy a hazai elektronikus földügyi eljárások továbbfejlesztésével kapcsolatos tendenciák illeszkednek az uniós elöírásokhoz, az elektronizációs folyamatok - uniós és hazai támogatással - sikerrel biztosíthatják a digitális világban is az ingatlanokhoz kapcsolódó jogok és tények közhiteles nyilvántartását. Így véleményem szerint már csak a nemzetközi tendenciákhoz igazodás sebességén múlik az, hogy a hazai ingatlan-nyilvántartás teljes körü elektronizációja mely lépések megvalósításával, milyen ütemben történik meg, és melyek azok a hazai telekkönyvi jogfejlődés szempontjából kerülendő irányok vagy módszerek, amelyek a más jogfejlődést magukénak tudó államokban esetleg működőképesek lehetnek, hazánkban azonban kudarcra lennének ítélve.

Úgy vélem, hogy az ingatlanokat érintő egyes jogok bejegyzése (elsősorban az egyszerübb jogügyletek) esetében vagy a már túlnyomó részt ma is elektronikusan zajló eljárások (mint például az ingatlanok címének tulajdoni lapokon történő automatikus átvétele a KCR-ből, azaz a Központi Címregiszterből) mintájára elindulhat az elektronizált eljárások körének bővítése.

Azonban meglátásom szerint a legrosszabb, ami történhet, hogy a hazánkban lezajló fokozatos - épp ezért a jogalkalmazók által is követhetö, és emiatt biztonságos, hiszen a résztvevők a változásokhoz megfelelő módon tudnak alkalmazkodni - változások helyett egy drasztikus átállás következne be, amely idegen a jelenlegi magánjogi rendszerünktől,

Uo.

2007/02/EK irányelv az Európai Közösségen belüli térinformációs infrastruktúra (INSPIRE) kialakításáról.

Mihály Szabolcs: Nemzeti Téradat Infrastruktúra Program. Székesfehérvár, GIS OPEN 2006 konferencia, 2006. 
felkészületlenül éri a többezer földügyi eljárásokban közreműködő hivatalnokot, pénzintézetet, különféle hatóságokat. És bár a magánszemélyeket látszólag kényelmesen, akár otthonról elérhető szolgáltatásokkal kényeztetheti a teljesen elektronikus földügyi igazgatás, de a jelenlegi kontrollmechanizmusok hirtelen kiiktatása minden bizonnyal bennük is bizalmatlanságot szülne, ami az egész ingatlan-nyilvántartási rendszer mellözéséhez, megkerüléséhez, devalválódásához és végül összeomlásához vezetne, ahogy azt a korábbi magyar példákból már láthattuk.

Az elektronizálási folyamat általam javasolható és Ausztriában is sikerrel alkalmazott technikája összhangban áll az Eüsztv. elöírásaival is, amely alapján az elektronikus ügyintézést biztosító szerv automatikus döntéshozatal esetén a rendelkezésére álló, valamint az automatikus információátvétel útján megszerzett adatok alapján, emberi közbeavatkozás nélkül hozza meg a döntését, és közli azt az ügyféllel. ${ }^{70}$ Azonban pusztán az automatikus döntéshozatallal egy-egy ingatlanokkal összefüggő jogügylethez tartozó „részfolyamat" fejlesztése nem jelenthet komplex megoldást.

70 Boros Anita: A magyar közigazgatási eljárásjog harmadik generációs törvénye: az Ákr. (II.) Új Magyar Közigazgatás, 11. (2018), 2. 31-40. 


\section{FELHASZNÁLT IRODALOM}

1. Berczi Norbert: Tájékoztató a földügyi szakág fejlesztési elképzeléseiröl. Geodézia és Kartográfia, 55. (2003), 9. 6-11.

2. Boros Anita: A magyar közigazgatási eljárásjog harmadik generációs törvénye: az Ákr. (II.) Új Magyar Közigazgatás, 11. (2018), 2. 31-40.

3. Boros Anita - Pollák Kitti: A hatóság döntései. In Boros Anita - Darák Péter szerk.: Az általános közigazgatási rendtartás szabályai. Budapest, Nemzeti Közszolgálati Egyetem, 2019.

4. Boros Anita - Vincze-Csapó Emese - Jugovits Károly: Az alapeljárási szabályok szabályozási karakterisztikája (1957-2018). In Boros Anita - Patyi András (szerk.): A hazai közigazgatási hatósági eljárási jog karakterisztikája. Budapest, Dialóg Campus, 2019. 135-196.

5. Csernok Nándor: Nulladik születésnap amit csendben (sem) ünnepeltünk meg. (avagy egy projekt alulnézetből). Geodézia és Kartográfia, 50. (1998), 7. 30-37.

6. Fehérváry Jenő: A magyar telekkönyvi jog vázlata. Budapest, Grill Károly Könyvkiadóvállalata, 1947.

7. Fenyö György - Hidvéginé Erdélyi Erika - Papp Iván: Magyar ingatlan-nyilvántartási jog. Székesfehérvár, Nyugat-Magyarországi Egyetem Geoinformatikai Kar Általános Jogi Tanszék, 2007.

8. Hajdu Tádé Miklós - Jánossy András: Magyar szemmel az osztrák ingatlan-nyilvántartásról. Geodézia és Kartográfia, 69. (2017), 4. 22-23.

9. Horváth Attila: A magyar magánjog történetének alapjai. Budapest, Gondolat, 2006.

10. Káplány Géza: Telekkönyv, birtokrendezés, telekkönyvi átalakitás, betétszerkesztés - Telekkönyv I. Budapest, Athenaeum R. Társulat, 1890.

11. Kenyeres János - Lovászy Csaba - Méhes Tamás - Péterfalvi Attila - Sárközy Szabolcs - Török Gábor: A magánjog alapjai. Budapest, HVG-ORAC, 2007. 120-124.

12. Kurucz Mihály (2003-2004): Ingatlan-nyilvántartási jog. ELTE Jogi Továbbképző Intézet Ingatlanforgalmi szakjogász képzés jegyzet.

13. Matúz György: Telekkönyvi rendszerünk kialakulása és működése. Doktori értekezés rövidített változata. Szegedi Tudományegyetem Állam- és Jogtudományi Kar, 2003.

14. Méhes Tamás: Birtokpolitika - A földszerzés elmélete és gyakorlata. Acta Humana, 5. (2017), 3. 47-69.

15. Méhes Tamás: Polgári jogi alapismeretek. Budapest, Nemzeti Közszolgálati Egyetem Államtudományi és Közigazgatási Kar, 2017.

16. Méhes Tamás: A Polgári Törvénykönyv vázlata. Budapest, Dialóg Campus, 2017.

17. Mihály Szabolcs: Nemzeti Téradat Infrastruktúra Program. Székesfehérvár, GIS OPEN 2006 konferencia, 2006.

18. Miniszterelnökség: Elektronikus ügyiratforgalmi statisztika. Elektronikus ügyintézés az ingatlan-nyilvántartásban 2019. II. félév 
19. Niklasz László: A „földhivatalok számítógépesítése” c. PHARE-projekt - TAKAROS, a digitális kataszteri térképek nyilvántartásának és kezelésének földhivatali koncepciója. Geodézia és Kartográfia, 46. (1995), 2. 90-93.

20. Sárffy Andor: Telekkönyvi rendtartás. Budapest, A szerző kiadása, 1941.

21. Schnierer Gyula: Jelzálogi- és telekkönyvi rendszerek elmélete. Pest, Lauffer Vilmos, 1869.

22. Snäll, Mats: Blockchain and the Land Register - a new "trust machine"? BlockchainExpo Global 2018. London, 2018. április 18-19.

23. Szabó Béla - Weninger Zoltán: Befejeződött a TAKAROS és a TAKARNET információ-technológiai rendszer országos telepítése. Geodézia és Kartográfia, 52. (2000), 8. 34-38.

24. Tóth Balázs: Elektronikus ügyintézés az ingatlan-nyilvántartásban. II. e-Cégkapu Konferencia, 2018. december 11.

25. Varga Márk: A 2015. év margójára. Geodézia és Kartográfia, 68. (2016), 3-4. 4-6.

26. Varga Márk: A telek- és jelzálogkönyvek magyarországi kialakulása és annak előzményei nemzetközi kitekintésben: Az 1855. évi telekkönyvi rendtartás. In Méhes Tamás - Téglási András (szerk.): A jövő közigazgatás-tudománya: A Közigazgatástudományi Doktori Iskola doktoranduszainak jubileumi tanulmánykötete. Budapest, Dialóg Campus, 2018.

27. Vos, Jacob-Christian Lemmen - Bert Beentjes: Blockchain-based Land Administration Feasible, Illusory or a Panace? Responsible Land Governance: Towards an Evidence Based Approach. Washington, D.C.: Annual World Bank Conference on Land and Property, 2017.

28. Zlinszky Imre: A magyar telekkönyvi rendtartás a mai érvényében. Budapest, Franklin Társulat, 1890.

Jogi források

1. 1723. évi CVII. törvénycikk a megyékben és városokban teljesitendő bejegyzésről vagy betáblázásról

2. 1840. évi XXI. törvénycikk adóssági követelések elsőbbség végetti betáblázásáról

3. 1886. évi XXIX. törvénycikk a telekkönyvi betétek szerkesztéséről

4. 1912. évi LIV. törvénycikk a polgári perrendtartásról szóló 1911. évi I. törvénycikk életbeléptetéséről

5. 1959. évi IV. törvény a Polgári Törvénykönyvről

6. 1994. évi V. törvény az ingatlan-nyilvántartásról szóló 1972. évi 31. törvényerejű rendelet módosításáról

7. 1997. évi CXLI. törvény az ingatlan-nyilvántartásról

8. 2013. évi V. törvény a Polgári Törvénykönyvről

9. 2013. évi CCXXXVII. törvény a hitelintézetekről és a pénzügyi vállalkozásokról

10. 2015. évi CCXXII. törvény az elektronikus ügyintézés és bizalmi szolgáltatások általános szabályairól

11. 2016. évi CXXX. törvény a polgári perrendtartásról 
12. 2016. évi CL. törvény az általános közigazgatási rendtartásról

13. 1972. évi 31. törvényerejü rendelet az ingatlan-nyilvántartásról

14. 126/1950. (IV. 29.) MT rendelet

15. 54/1960. (XI. 27.) Korm. rendelet a telekkönyvröl

16. 383/2016. (XII. 2.) Korm. rendelet a földművelésügyi hatósági és igazgatási feladatokat ellátó szervek kijelöléséröl

17. 27/1972. (XII. 31.) MÉM rendelet az ingatlan-nyilvántartásról szóló 1972. évi 31. törvényerejű rendelet végrehajtásáról

18. 109/1999. (XII. 29.) FVM rendelet az ingatlan-nyilvántartásról szóló 1997. évi CXLI. törvény végrehajtásáról

19. 2007/02/EK irányelv az Európai Közösségen belüli térinformációs infrastruktúra (INSPIRE) kialakításáról

\section{Internetes források}

1. Az Ingatlan-nyilvántartási joggyakorlat-elemzőcsoport összefoglaló véleménye. A Kúria Joggyakorlat-elemző Csoportja, 2016. Elérhető: https://kuria-birosag.hu/sites/default/ files/joggyak/az_ingatlan-nyilvantartasi_joggyakorlat-elemzo_csoport_osszefoglalo_ velemenye_1.pdf (A letöltés dátuma: 2020. 04. 23.)

2. Müszaki leírás az elektronikus ingatlan-nyilvántartás létrehozása érdekében infrastruktúra-felmérési, valamint adatbázis- és alkalmazásfejlesztési feladatok ellátása tárgyú közbeszerzési eljáráshoz. Lechner Tudásközpont Területi, Építészeti és Informatikai Nonprofit Kft. Elérhető: http://lechnerkozpont.hu/doc/kozbeszerzes/elektronikusingatlan-nyilvantartas-kozbeszerzes/muszaki-leiras-2018s-072-159701-20180413.pdf (A letöltés dátuma: 2020. 05. 05.)

3. Szilvay Gergely: TAKARNET24 szolgáltatásai. GISopen konferenciaelőadás, 2011. Elérhető: www.foldhivatal.hu/images/TakarNet24/gis-open_tk24_szig_2011.pdf (A letöltés dátuma: 2020.05. 05.)

Dr. Varga Márk LL.M. jelenleg a Nemzeti Közszolgálati Egyetem Közigazgatási Továbbképzési Intézet Igazgatói Iroda irodavezetője. A szerző a Nemzeti Közszolgálati Egyetem Közigazgatás-tudományi Doktori Iskola doktorandusza. Kutatási területe a magyar közigazgatás, valamint az önkormányzás története, ezen belül az általa kutatandó téma a telekkönyv intézményének történeti és nemzetközi összefüggései. Kutatásait szakmailag a több mint másfél évtizedes földügyi igazgatásban eltöltött időszak során szerzett ügyintézői, vezetői és ágazati felelősi tapasztalata alapozza meg. Ingatlanforgalmi szakjogász végzettségének megszerzése kapcsán is ennek a szakterületnek a mélyebb ismereteit sajátíthatta el, így mind elméleti, mind gyakorlati oldalról megfelelő módon megalapozta jelenleg folytatott kutatásait, amelyek elsősorban jogtörténeti jellegűek, másodsorban közigazgatási jogi, illetve polgári jogi természetüek. 